\title{
Capecitabine versus 5-fluorouracil in colorectal cancer: where are we now?
}

\author{
Lakshmi Chintala $\cdot$ Susmitha Vaka \\ Joaquina Baranda $\cdot$ Stephen K. Williamson
}

Received: 19 November 2010/Accepted: 2 March 2011/Published online: 9 April 2011

(c) The Author(s) 2011. This article is published with open access at Springerlink.com

\begin{abstract}
Fluorouracil (5-FU) remains the most widely used agent for colorectal cancer. Capecitabine is a rationally designed 5-FU pro-drug developed to mimic the continuous infusion of 5-FU while avoiding complications and inconvenience of intravenous administration. Capecitabine is absorbed intact from the gastrointestinal tract, converted enzymatically to active 5-FU, and released directly into the tumor. Capecitabine's efficacy and safety are shown in multiple phase III trials across different disease stages and therapy lines. Three randomized phase III trials demonstrated the equivalence of capecitabine plus oxaliplatin (XELOX) versus 5-FU/leucovorin (LV)/oxaliplatin (FOLFOX). The safety of capecitabine compared with 5-FU depends on the regimen of 5-FU used. The adverse event rate with oxaliplatin in combination with infusional 5-FU is similar to that of capecitabine plus oxaliplatin but is associated with more neutropenia and venous thrombotic events; capecitabine plus oxaliplatinbased regimens tend to be associated with more grade 3 diarrhea and hand-foot skin reaction. Combination therapy with capecitabine and irinotecan (CapeIRI) versus 5-FU/ LV and irinotecan (FOLFIRI) had more variable results; some former schedules resulted in excessive treatmentrelated toxicity. More recent data show that lower capecitabine and irinotecan doses, different schedules, and combination with targeted agents (e.g, bevacizumab) have resulted in more favorable outcomes.
\end{abstract}

L. Chintala $\cdot$ S. Vaka $\cdot$ J. Baranda $\cdot$ S. K. Williamson ( $₫)$

Division of Hematology/Oncology,

University of Kansas Cancer Center,

2330 Shawnee Mission Parkway, Suite 210,

Westwood, KS 66205, USA

e-mail: swilliam@kumc.edu
Keywords Capecitabine $\cdot$ Chemotherapy $\cdot$ Colorectal cancer $\cdot$ Combination therapy $\cdot$ Fluorouracil

\section{Introduction}

The most widely used agent in the treatment of colorectal cancer (CRC) is fluorouracil (5-FU), which was developed more than 50 years ago by Heidelberger et al. [1]. 5-FU enters a complex anabolic process that interferes with normal DNA and RNA functions and accounts for cytotoxicity at the cellular level. Because of poor oral absorption and intra-patient variability, 5-FU is most often administered intravenously (IV) as a rapid bolus injection; it is rapidly distributed, with triphasic elimination [2]. Preclinical studies suggested that 5 -FU is a time-dependent drug, and that cytotoxicity increases with prolonged exposure [2-4]. Therefore, clinical trials were initiated with 5-FU administered for extended periods $[5,6]$. Response rates in CRC increased with continuous infusion compared with bolus administration, with a more acceptable toxicity profile $[7,8]$. Nevertheless, the inconvenience of protracted IV administration provided a strong impetus for the development of oral fluoropyrimidines that could be taken conveniently on a schedule that simulates continuous infusion [9].

Capecitabine is an example of a rationally designed 5-FU pro-drug intended to mimic the continuous infusion of 5-FU while avoiding the complications and inconvenience associated with IV drug administration. It is a fluoropyrimidine carbamate that is converted to the active 5-FU by the action of three enzymes: an esterase, a deaminase, and a phosphorylase [9]. In the third step, the enzyme thymidine phosphorylase (TP) converts $5^{\prime}$-deoxy5-fluorouridine to 5-FU, which is released directly into 
tumor tissue [10]. The enzyme TP has higher concentrations in many tumor types compared with matched normal tissue and is particularly higher in excised human colon cancer [11]. This suggests that higher tumor concentrations of 5-FU might be expected, due to a higher production of active drug in the tumor tissue, thereby providing a favorable target-to-non-target ratio for toxicity. Tumor selectivity and conversion of capecitabine to active 5-FU within the tumor tissue have been confirmed in human samples that show a 3.2-fold higher concentration of 5-FU in tumor compared with normal tissue and a 21-fold higher tumor-to-plasma ratio. In comparison, when IV 5-FU is administered, either by bolus or continuous infusion, the concentration of active drug in tumor is not higher than that in normal tissue [11]. The greater levels of the TP enzyme in tumor tissue allow for targeted intra-tumoral release of 5-FU and subsequently less systemic toxicity compared with infusions of 5-FU [12].

This review provides an up-to-date literature review and overview of how capecitabine compares with 5-FU as a single agent as well as in combination with oxaliplatin or irinotecan, and in combination with targeted therapy, in the treatment of CRC. We review the available phase I, II, and III clinical trials conducted in patients with CRC that document the metabolic activation of this compound and support its use in patients with advanced CRC and how the drug may be incorporated into the standard care of patients with CRC.

\section{Clinical efficacy and tolerability}

Various schedules of single-agent capecitabine were tested in three phase I trials (Table 1). These trials revealed that intermittent dosing allowed for higher doses of capecitabine but at the expense of increased hand-foot syndrome (HFS). Diarrhea was the dose-limiting toxicity in all treatment schedules [13-15]. A randomized phase II trial was performed to further define activity and the optimum schedule to carry forward into phase III trials. In this study, metastatic CRC (mCRC) patients were randomized between the three leading schedules of capecitabine [continuous, intermittent, or intermittent with leucovorin (LV)]. No difference in overall survival (OS) was noted between the arms; however, significant improvement in disease progression was observed for the single-agent intermittent schedule. The intermittent schedule without LV was recommended for phase III study based on its improved progression-free survival (PFS), the high dose intensity, and better therapeutic index [16].

\section{Capecitabine as a single agent}

Two multicenter, randomized, phase III studies were conducted (1 in North America, 1 in Europe) comparing capecitabine with IV 5-FU/LV as first-line therapy in metastatic CRC patients. The trials were identical with respect to study design, inclusion and exclusion criteria, primary end point of overall response rate (RR), and secondary end points such as median time to disease progression, median time to treatment failure, and OS times, in order that subsequent pooling of results could be performed (Table 2) [17-19].

Patients were randomly assigned to either capecitabine in an intermittent regimen of 3-week cycles or 5-FU/LV, administered according to the Mayo Clinic regimen (5-FU $425 \mathrm{mg} / \mathrm{m}^{2}$ plus LV $20 \mathrm{mg} / \mathrm{m}^{2}$ administered IV for 5 days every 28 days). The Mayo Clinic regimen was chosen as a control arm for both studies, as it was the standard of care for front-line therapy of $\mathrm{mCRC}$ at the time of trial design $[17,18]$.

Table 1 Capecitabine in phase I trials

\begin{tabular}{|c|c|c|c|c|}
\hline References & $\begin{array}{l}\text { Patients } \\
\text { enrolled } \\
(N)\end{array}$ & Regimen & Response & Safety, tolerability \\
\hline $\begin{array}{l}\text { Budman et al. } \\
\text { [13] }\end{array}$ & 33 & $\begin{array}{l}110-1,675 \mathrm{mg} / \mathrm{m}^{2} / \text { day continuously } \\
\text { in two equally divided doses; } \\
1,331 \mathrm{mg} / \mathrm{m}^{2} \text { established as phase } \\
\text { II dose }\end{array}$ & $\begin{array}{l}\text { One patient with a mixed response; } \\
\text { one with SD after } 18 \text { months of } \\
\text { therapy }\end{array}$ & $\begin{array}{l}\text { Diarrhea and HFS were the most } \\
\text { common dose-limiting toxicities }\end{array}$ \\
\hline $\begin{array}{l}\text { Mackean et al. } \\
{[14]}\end{array}$ & 34 & $\begin{array}{l}502-3,414 \mathrm{mg} / \mathrm{m}^{2} / \text { day in two equally } \\
\text { divided doses for } 14 \text { days followed } \\
\text { by } 7 \text { days' rest; } 2,510 \mathrm{mg} / \mathrm{m}^{2} / \text { day } \\
\text { recommended as phase II dose }\end{array}$ & $\begin{array}{l}\text { Objective tumor response in five } \\
\text { patients at } 2,510 \mathrm{mg} / \mathrm{m}^{2} \text {; one } \mathrm{CR} \\
\text { and three PRs }\end{array}$ & $\begin{array}{l}\text { HFS at higher doses for extended } \\
\text { times }\end{array}$ \\
\hline $\begin{array}{l}\text { Cassidy et al. } \\
\text { [15] }\end{array}$ & 31 & $\begin{array}{l}1,004-2,510 \mathrm{mg} / \mathrm{m}^{2}+\mathrm{LV} 60 \mathrm{mg} \text { bid } \\
\text { for } 14 \text { days followed by } 7 \text { days' rest; } \\
1,650 \mathrm{mg} / \mathrm{m}^{2} / \text { day C }+60 \mathrm{mg} \mathrm{LV} \\
\text { recommended as phase II dose }\end{array}$ & Two PRs & $\begin{array}{l}\text { Dose-limiting AEs at } 2,000 \mathrm{mg} / \\
\mathrm{m}^{2} / \text { day included nausea, } \\
\text { diarrhea, vomiting, and HFS }\end{array}$ \\
\hline
\end{tabular}

$A E s$ adverse events, bid twice a day, $C$ capecitabine, $C R$ complete response, $H F S$ hand-foot syndrome, $L V$ leucovorin, $P R s$ partial responses, $S D$ stable disease 
Table 2 Capecitabine as a single agent in phase III trials

\begin{tabular}{|c|c|c|c|c|c|c|}
\hline References & $\begin{array}{l}\text { Patients } \\
\text { enrolled } \\
(N)\end{array}$ & Regimen & Response rate & $\begin{array}{l}\text { Median time to } \\
\text { disease } \\
\text { progression }\end{array}$ & $\begin{array}{l}\text { Median } \\
\text { overall } \\
\text { survival }\end{array}$ & Safety, tolerability \\
\hline $\begin{array}{l}\text { Hoff et al. } \\
\text { [12] }\end{array}$ & 605 & $\begin{array}{l}1,250 \mathrm{mg} / \mathrm{m}^{2} \text { bid for } 14 \text { days } \\
\text { followed by } 7 \text { days' rest or } \\
\text { 5-FU/LV (Mayo Clinic) }\end{array}$ & $\begin{array}{l}24.8 \%(\mathrm{C}) \mathrm{vs} . \\
15.5 \%(5-\mathrm{FU}) \\
(P=0.005)\end{array}$ & $\begin{array}{l}4.3(\mathrm{C}) \text { vs. } \\
4.7 \text { months } \\
(5-\mathrm{FU})\end{array}$ & $\begin{array}{l}12.5(\mathrm{C}) \text { vs. } \\
13.3 \text { months } \\
(5-\mathrm{FU}) \\
P=0.974\end{array}$ & $\begin{array}{l}\text { Lower rate of diarrhea, } \\
\text { stomatitis, nausea, and } \\
\text { alopecia with C vs. 5-FU; } \\
\text { higher rate of HFS and } \\
\text { hyperbilirubinemia } \\
\text { with C vs. 5-FU }\end{array}$ \\
\hline $\begin{array}{l}\text { Van Cutsem } \\
\text { et al. [18] }\end{array}$ & 602 & $\begin{array}{l}1,250 \mathrm{mg} / \mathrm{m}^{2} \text { bid for } 14 \text { days } \\
\text { followed by } 7 \text { days' rest or } \\
\text { 5-FU/LV (Mayo Clinic) }\end{array}$ & $\begin{array}{c}18.9 \% \text { (C) vs. } \\
15 . \%(5-\mathrm{FU})\end{array}$ & $\begin{array}{l}5.2(\mathrm{C}) \text { vs. } \\
4.7 \text { months } \\
(5-\mathrm{FU})\end{array}$ & $\begin{array}{l}13.2(\mathrm{C}) \text { vs. } \\
12.1 \text { months } \\
(5-\mathrm{FU}) \\
P=0.33\end{array}$ & $\begin{array}{l}\text { Lower rate of diarrhea, } \\
\text { stomatitis, nausea, and } \\
\text { alopecia with C vs. 5-FU; } \\
\text { higher rate of HFS and } \\
\text { hyperbilirubinemia } \\
\text { with C vs. 5-FU }\end{array}$ \\
\hline
\end{tabular}

Bid twice a day, $C$ capecitabine, 5-FU fluorouracil, $H F S$ hand-foot syndrome, $L V$ leucovorin

In both studies, RRs were higher for capecitabine compared with 5-FU/LV: 25.8 versus $11.6 \%(P=0.005)$ and 18.9 versus $15 \%$, respectively. Although capecitabine demonstrated higher RRs, median time to disease progression and median OS did not differ significantly between the arms in both studies. Compared with the 5-FU/ LV group, patients in the capecitabine group experienced a significantly lower incidence of any grade diarrhea, stomatitis, nausea, and alopecia, but a higher incidence of HFS and hyperbilirubinemia [19]. These trials demonstrated that capecitabine monotherapy is a reasonable alternative for patients with $\mathrm{mCRC}$.

Capecitabine in combination with oxaliplatin or irinotecan

The combination of the cytotoxic agents oxaliplatin and irinotecan, and targeted agents such as cetuximab, panitumumab, and bevacizumab with 5-FU, have significantly improved survival rates for patients with $\mathrm{mCRC}$ and are now the standard of care. Therefore, based on similar efficacy and reduced toxicity compared with bolus 5-FU regimens, capecitabine was tested in combination with the cytotoxic agents oxaliplatin and irinotecan.

Preclinical models have demonstrated that the combination of capecitabine and oxaliplatin is a rational combination therapy for the treatment of CRC. In a human tumor xenograft model, the combination of capecitabine and oxaliplatin inhibited the in vivo growth of CXF280 human CRC more effectively than either agent alone [20].

A phase I study in patients with metastatic solid tumors demonstrated that the combination of capecitabine with oxaliplatin is feasible and established the recommended dose regimen as IV oxaliplatin $130 \mathrm{mg} / \mathrm{m}^{2}$ on day 1 , with oral capecitabine $1,000 \mathrm{mg} / \mathrm{m}^{2}$ twice daily on days $1-14$ in a 3-week cycle [21]. When this regimen was evaluated in a phase II study in patients with mCRC, the RRs ranged between 45 and $55 \%$, with sensory neuropathy (17\%), diarrhea $(16 \%)$, and nausea and vomiting $(13 \%)$ as the most common treatment-related adverse events (AEs) [22].

Three randomized phase III studies, one of which was published only in abstract form, demonstrated the equivalence of capecitabine with oxaliplatin (XELOX) in comparison with 5-FU/LV/oxaliplatin (FOLFOX) as first- and second-line therapy of mCRC (Table 3) [23-25]. Patients were randomly assigned to a regimen of XELOX or FOLFOX-4. ${ }^{1}$ These trials demonstrated that XELOX is equivalent to FOLFOX with respect to PFS when used as first- or second-line therapy in patients with mCRC. Treatment-related grade 3/4 AEs such as neutropenia/ granulocytopenia (35 vs. 5\%) and febrile neutropenia (4 vs. $<1 \%$ ) were more frequent with FOLFOX-4 than with XELOX, though grade 3 diarrhea (19 vs. 5\%) and HFS (4 vs. $<1 \%$ ) were higher for the XELOX regimen [23-25].

A pooled analysis of six randomized phase II/III trials evaluating the role of oxaliplatin in combination with capecitabine or infusional 5-FU included 3,494 patients with mCRC and demonstrated similar PFS and OS in patients treated with the two regimens. However, patients treated with XELOX had lower RRs. In this review, FOLFOX demonstrated a statistically significant RR of $41-52 \%$ as compared to XELOX, with an RR of $27-48 \%$ $(P=0.02)$ [26]. Thus, the use of XELOX is a valid alternative regimen for patients with $\mathrm{mCRC}$.

Capecitabine in combination with irinotecan was extensively studied in a wide range of schedules in

\footnotetext{
$\overline{{ }^{1} \text { FOLFOX-4 }}=$ oxaliplatin $85 \mathrm{mg} / \mathrm{m}^{2}$ on day 1 only given as a 2-hour infusion concurrent with $\mathrm{LV}$ at $200 \mathrm{mg} / \mathrm{m}^{2} / \mathrm{d}$ followed by bolus 5 -FU $400 \mathrm{mg} / \mathrm{m}^{2} / \mathrm{d}$ and a 22 -hour infusion of $5-\mathrm{FU} 600 \mathrm{mg} / \mathrm{m}^{2} / \mathrm{d}$, repeated for 2 consecutive days every 2 weeks.
} 
Table 3 Capecitabine and oxaliplatin

\begin{tabular}{|c|c|c|c|c|c|c|}
\hline References & $\begin{array}{l}\text { Study phase, } \\
\text { patients enrolled }\end{array}$ & Regimen & Response rate $(\%)$ & $\begin{array}{l}\text { Median } \\
\text { progression-free } \\
\text { survival }\end{array}$ & $\begin{array}{l}\text { Median overall } \\
\text { survival }\end{array}$ & Safety, tolerability \\
\hline $\begin{array}{l}\text { Rothenberg } \\
\text { et al. [24] }\end{array}$ & $\begin{array}{l}\text { Phase III, } \\
\quad N=627\end{array}$ & $\begin{array}{l}\text { XELOX (2-h IV infusion Ox } \\
130 \mathrm{mg} / \mathrm{m}^{2} \text { on day } 1+\mathrm{C} \\
1,000 \mathrm{mg} / \mathrm{m}^{2} \text { bid on days } \\
1-15 \text { of a } 3 \text {-week cycle) or } \\
\text { FOLFOX-4 (Ox } 85 \mathrm{mg} / \mathrm{m}^{2} \\
\text { on day } 1 \text { as a } 2-\mathrm{h} \text { infusion } \\
\text { concurrent with LV } \\
200 \mathrm{mg} / \mathrm{m}^{2} / \text { day followed } \\
\text { by bolus } 5 \text {-FU } 400 \mathrm{mg} / \mathrm{m}^{2} / \\
\text { day }+22-\mathrm{h} \text { infusion of } \\
5 \text {-FU } 600 \mathrm{mg} / \mathrm{m}^{2} / \text { day) } \\
\text { repeated for two } \\
\text { consecutive days every } \\
2 \text { weeks }\end{array}$ & $\begin{array}{l}\text { ORR: } 20 \text { (XELOX) } \\
\text { vs. } 18 \% \\
\text { (FOLFOX-4) }\end{array}$ & $\begin{array}{l}4.7 \text { (XELOX) } \\
\text { vs. } 4.8 \text { months } \\
\text { (FOLFOX4) } \\
\text { (ITT); } \\
\text { XELOX } \\
\text { noninferior to } \\
\text { FOLFOX-4 }\end{array}$ & $\begin{array}{l}11.9 \text { (XELOX) } \\
\text { vs. } \\
12.5 \text { months } \\
\text { (FOLFOX- } \\
\text { 4) (ITT) }\end{array}$ & $\begin{array}{l}\text { Grade } 3 / 4 \text { AEs: } 65 \text { vs. } 50 \% \text {; } \\
\text { grade } 4 \text { AEs: } 18 \text { vs. } 3 \% \text {; } \\
\text { febrile neutropenia: } 4 \text { vs. } \\
<1 \% \text {; grade } 3 \text { diarrhea: } \\
5 \text { vs. } 19 \% \text {, FOLFOX-4 vs. } \\
\text { XELOX, respectively }\end{array}$ \\
\hline $\begin{array}{l}\text { Cassidy } \\
\text { et al. [23] }\end{array}$ & $\begin{array}{l}\text { Phase III, } \\
\quad N=2,034\end{array}$ & $\begin{array}{l}\text { XELOX OR FOLFOX-4 B at } \\
7.5 \mathrm{mg} / \mathrm{kg} \text { or PBO added to } \\
\text { XELOX every third week } \\
\text { and B at } 5 \mathrm{mg} / \mathrm{kg} \text { or PBO } \\
\text { added to FOLFOX-4 every } \\
\text { third week }\end{array}$ & $\begin{array}{l}\text { ORR: } 47 \text { (XELOX) } \\
\text { vs. } 48 \% \\
\text { (FOLFOX-4) }\end{array}$ & $\begin{array}{l}8.0 \text { (pooled } \\
\text { XELOX arms) } \\
\text { vs. } 8.5 \text { months } \\
\text { (FOLFOX-4) }\end{array}$ & $\begin{array}{l}19.8 \text { (pooled } \\
\text { XELOX } \\
\text { arms) vs. } \\
19.6 \text { months } \\
\text { (pooled } \\
\text { FOLFOX-4 } \\
\text { arms) }\end{array}$ & $\begin{array}{l}\text { Rates of grade } 3 / 4 \text { AEs } \\
\text { similar in both arms; grade } \\
4 \text { AEs more common with } \\
\text { FOLFOX-4 due to grade } 4 \\
\text { neutropenia. XELOX } \\
\text { associated with more grade } \\
3 \text { diarrhea and HFS }\end{array}$ \\
\hline $\begin{array}{l}\text { Ducreux } \\
\text { et al. [25] }\end{array}$ & $\begin{array}{l}\text { Phase III; } \\
\begin{array}{l}N=306 \text { (ITT); } \\
N=284 \text { (PP) }\end{array}\end{array}$ & $\begin{array}{l}\text { XELOX OR FOLFOX-6 } \\
\left(\text { Ox } 100 \mathrm{mg} / \mathrm{m}^{2} \text { day, LV }\right. \\
400 \mathrm{mg} / \mathrm{m}^{2} 2-\mathrm{h} \text { infusion, } \\
\text { then } 5-\mathrm{FU} 400 \mathrm{mg} / \mathrm{m}^{2} \mathrm{IV} \\
\text { bolus, then } \\
2,400-3,000 \mathrm{mg} / \mathrm{m}^{2} 46 \mathrm{~h} \\
\text { infusion) every } 2 \text { weeks for } \\
6 \text { months }\end{array}$ & $\begin{array}{l}\text { RR (PP): } 42 \text { vs. } \\
46 \% \text { (XELOX vs. } \\
\text { FOLFOX-6) }\end{array}$ & $\begin{array}{l}\text { PP: } 9.3 \text { vs. } \\
9.7 \text { months } \\
\text { (XELOX vs. } \\
\text { FOLFOX-6) }\end{array}$ & $\begin{array}{l}\text { PP: } 19.9 \text { vs. } \\
18.4 \text { months } \\
\text { (XELOX vs. } \\
\text { FOLFOX-6) }\end{array}$ & $\begin{array}{l}\text { Grade } 3 / 4 \text { HFS: } 3 \text { vs. } 0 \% \text {; } \\
\text { thrombocytopenia: } 12 \text { vs. } \\
\text { 5\%; diarrhea: } 12 \text { vs. } 7 \% \text {; } \\
\text { grade } 3 / 4 \text { neutropenia: } 0 \text { vs. } \\
\text { 6\%; neuropathy: } 8 \text { vs. } 19 \% \\
\text { (XELOX vs. FOLFOX-6) }\end{array}$ \\
\hline
\end{tabular}

AEs adverse events, $B$ bevacizumab, bid twice a day, $C$ capecitabine, 5-FU fluorouracil, FOLFOX fluorouracil/leucovorin/oxaliplatin, $H F S$ hand-foot syndrome, ITT intent-to-treat, $I V$ intravenous, $L V$ leucovorin, $O x$ oxaliplatin, $O R R$ overall response rate, $P B O$ placebo, $P P$ per protocol, XELOX capecitabine plus oxaliplatin

different regimens (i.e., 2-weekly, 3-weekly, 4-weekly, 6-weekly, and 7-weekly) [27-30]. Reports of excessive and overlapping toxicities, specifically of gastrointestinal origin, prompted alterations in the dose and administration schedule. Promising results were demonstrated from a phase II trial evaluating capecitabine in combination with irinotecan administered every 2 weeks. This trial demonstrated a median time to progression of 8.4 months, a median duration of response of 7.3 months, and an OS of 19.3 months (Table 4) [30].

The BICC-C (Bolus, Infusional, or Capecitabine with Camptosar-Celecoxib), a randomized phase III trial explored three combinations of irinotecan-based regimens. In this study, 430 previously untreated mCRC patients randomized to FOLFIRI (irinotecan plus infusional 5-FU/ LV), mIFL (irinotecan plus bolus 5-FU/LV), or CapeIRI (irinotecan plus capecitabine), all in combination with celecoxib (Table 4) [27]. The CapeIRI arm was discontinued early in the trial because of unacceptable toxicity. In addition, the trial was amended to add bevacizumab to the
FOLFIRI and mIFL arms. Adding bevacizumab improved PFS for both FOLFIRI and mIFL, from 7.6 to 11.2 months and from 5.9 to 8.3 months, respectively. The OS for the FOLFIRI and bevacizumab arm was 23.1 months. Inferior efficacy results for CapeIRI might reflect early treatment discontinuation as a result of toxicity, or an interaction with celecoxib [27].

EORTC 40015 compared FOLFIRI and CapeIRI in 85 patients in the second line setting for mCRC. There was sub-randomization to celecoxib versus placebo, and median PFS and OS times were shorter for CapeIRI versus FOLFIRI and for celecoxib versus placebo. The trial was closed early following 8 deaths in the 85 patients enrolled, mostly related to gastrointestinal or thromboembolic events, but not related to disease progression. Given the small number of patients and early closure of the study, it is hard to draw meaningful conclusions [28]. Another phase III trial evaluating sequential chemotherapy versus initial combination chemotherapy with CapeIRI demonstrated a longer PFS for the combination regimen at the expense of 
Table 4 Capecitabine and irinotecan

\begin{tabular}{|c|c|c|c|c|c|c|}
\hline Study & $\begin{array}{l}\text { Study } \\
\text { phase, } \\
\text { patients } \\
\text { enrolled }\end{array}$ & Regimen & Response rate $(\%)$ & $\begin{array}{l}\text { Median } \\
\text { progression-free } \\
\text { survival }\end{array}$ & $\begin{array}{l}\text { Median overall } \\
\text { survival }\end{array}$ & Safety, tolerability \\
\hline $\begin{array}{l}\text { Fuchs } \\
\text { et al. } \\
{[27]}\end{array}$ & $\begin{array}{l}\text { Phase III, } \\
\quad N=430\end{array}$ & $\begin{array}{l}\text { Irinotecan }+ \text { infusional } \\
\text { 5-FU/LV (FOLFIRI) } \\
( \pm \mathrm{B}) \text { or } \\
\text { irinotecan }+ \text { bolus 5-FU/ } \\
\text { LV (mIFL) }( \pm \mathrm{B}) \text { or } \\
\text { irinotecan }+\mathrm{C} \\
\text { (CapeIRI) }\end{array}$ & $\begin{array}{l}\text { ORR: } 47.2 \\
\text { (FOLFIRI), } 43.3 \\
\text { (mIFL), 38.6\% } \\
\text { (CapeIRI), } \\
\text { (P=NS); CR: } 5.6 \\
\text { (FOLFIRI), } 4.3 \\
\text { (mIFL), } 2.8 \% \\
\text { (CapeIRI) }\end{array}$ & $\begin{array}{l}7.6 \text { (FOLFIRI) vs. } \\
5.9 \text { (mIFL) vs. } \\
5.8 \text { months } \\
\text { (CapeIRI) }\end{array}$ & $\begin{array}{l}23.1 \text { (FOLFIRI) } \\
\text { vs. } 17.6 \\
\text { (mIFL) vs. } \\
18.9 \text { months } \\
\text { (CapeIRI) } \\
(P=\text { NS) }\end{array}$ & $\begin{array}{l}\text { Higher rates of grade } 3 \\
\text { vomiting, diarrhea, HFS, } \\
\text { and dehydration } \\
\text { (CapeIRI vs. FOLFIRI) }\end{array}$ \\
\hline $\begin{array}{l}\text { Köhne } \\
\text { et al. } \\
\text { [28] }\end{array}$ & $\begin{array}{l}\text { Phase III, } \\
\quad N=85\end{array}$ & $\begin{array}{l}\text { FOLFIRI OR } \\
\text { CapeIRI } \pm \text { PBO or } \\
\text { celecoxib }\end{array}$ & $\begin{array}{l}\text { OS: } 14.8 \text { vs. } \\
19.9 \text { months } \\
\text { (CAPIRI vs. } \\
\text { FOLFIRI); OS: } 18.3 \\
\text { vs. } 19.9 \text { months } \\
\text { (celecoxcib vs. } \\
\text { PBO) }\end{array}$ & $\begin{array}{l}\text { PFS: } 5.9 \text { vs. } 9.6 \\
\text { (CAPIRI vs. } \\
\text { FOLFIRI) PFS: } \\
6.9 \text { vs. } 7.8 \\
\text { (celecoxib vs. } \\
\text { PBO) }\end{array}$ & $\begin{array}{l}14.75 \text { vs. } \\
19.9 \text { months } \\
\text { (CapeIRI vs. } \\
\text { FOLFIRI) }\end{array}$ & $\begin{array}{l}8 \text { deaths unrelated to } \\
\text { disease progression; } \\
\text { grade 3/4 AEs: } 74 \text { vs. } \\
49 \% \text {.(CapeIRI vs. } \\
\text { FOLFIRI) }\end{array}$ \\
\hline $\begin{array}{l}\text { Koopman } \\
\text { et al. } \\
\text { [29] }\end{array}$ & $\begin{array}{l}\text { Phase III, } \\
\quad N=803\end{array}$ & $\begin{array}{l}\text { Sequential therapy: first- } \\
\text { line C followed by } \\
\text { second-line irinotecan } \\
\text { followed by third-line } \\
\mathrm{C}+\text { Ox or CapeIRI } \\
\text { followed by C + Ox } \\
\text { second-line }\end{array}$ & OS: NS between arms & $\begin{array}{l}\text { PFS in first-line } \\
\text { treatment was } \\
\text { significantly } \\
\text { longer in } \\
\text { combination vs. } \\
\text { sequential arm } \\
(P=0.0002)\end{array}$ & $\begin{array}{l}\text { Median } \\
\text { survival: } 16.3 \\
\text { vs. } 17.4 \\
\text { months } \\
\text { (sequential vs. } \\
\text { combination); } \\
P=\text { NS }\end{array}$ & $\begin{array}{l}\text { Grade } 3 / 4 \text { toxicity greater } \\
\text { in combination than } \\
\text { sequential arm; diarrhea: } \\
26 \text { vs. } 11 \% \text {; grade } 3 / 4 \\
\text { HFS: } 12 \text { vs. } 6 \% \\
\text { (combination vs. } \\
\text { sequential arm) }\end{array}$ \\
\hline $\begin{array}{l}\text { Garcia } \\
\text { Alfonso } \\
\text { et al. } \\
\text { [30] }\end{array}$ & $\begin{array}{l}\text { Phase II, } \\
N=35\end{array}$ & $\begin{array}{l}\text { Irinotecan } 175 \mathrm{mg} / \mathrm{m}^{2} \text { on } \\
\text { day } 1+\mathrm{C} 1,000 \mathrm{mg} / \mathrm{m}^{2} \\
\text { bid on days } 2-8, \text { repeated } \\
\text { every } 14 \text { days }\end{array}$ & $\begin{array}{l}\text { CR: } 7.5 \% \text {; PR: } 32 \% \text {; } \\
\text { SD: } 36 \% \text {; PD: } 19 \% \text {; } \\
\text { ORR: } 40 \%\end{array}$ & $\begin{array}{l}\text { Median TTP: } \\
8.4 \text { months; } \\
\text { median duration } \\
\text { of relapse: } \\
7.3 \text { months }\end{array}$ & 19.3 months & Manageable \\
\hline
\end{tabular}

AEs adverse events, $B$ bevacizumab, $C$ capecitabine, CapeIRI capecitabine and irinotecan, $C R$ complete response, FOLFIRI fluorouracil/ leucovorin/irinotecan, 5-FU fluorouracil, $H F S$ hand-foot syndrome, $L V$ leucovorin, $m I F L$ irinotecan plus bolus fluorouracil/leucovorin, $N S$ not significant, $O R R$ overall response rate, $O S$ overall survival, $O x$ oxaliplatin, $P B O$ placebo, $P D$ progressive disease, $P F S$ progression-free survival, $P R$ partial response, $S D$ stable disease, TTP time to progression

greater toxicity [29]. Capecitabine and irinotecan combinations have similar activity as 5-FU and irinotecan regimens, but greater toxicity. Further studies to determine the most appropriate dose of capecitabine in combination with irinotecan and in other combination regimens for particular geographic and/or ethnic patient groups may be warranted.

Combination chemotherapy with targeted agents such as bevacizumab or cetuximab

Targeted therapies with vascular endothelial growth factor (VEGF) inhibitors such as bevacizumab, and epidermal growth factor receptor (EGFR) inhibitors such as cetuximab or panitumumab, have become a significant part of the management of $\mathrm{mCRC}$.

VEGF is the central regulator of angiogenesis. In recent years, considerable interest has developed regarding the importance of angiogenesis in tumor growth and progression [31]. Increased expression of VEGF in patients with colorectal carcinoma has been associated with early recurrence and poor prognosis [32]. In randomized phase III clinical trials in patients with $\mathrm{mCRC}$, bevacizumab improved RRs, OS, and PFS when combined with standard chemotherapies such as infusional 5-FU/LV plus irinotecan and FOLFOX [33, 34].

Given the improvement seen with addition of bevacizumab to 5-FU-containing regimens, new studies were designed to evaluate the combination of bevacizumab- and capecitabine-containing regimens. Results of the Three Regimens of Eloxatin Evaluation (TREE)-2 trial provided further evidence of increased efficacy when bevacizumab was added to oxaliplatin-based chemotherapeutic agents [35]. The TREE-1 and TREE-2 trials were sequentially conducted, randomized, phase II trials that initially tested three different oxaliplatin-fluoropyrimidine combination regimens. These included FOLFOX, oxaliplatin plus bolus 5-FU/LV (bFOL), or capecitabine plus oxaliplatin (CapeOx) as first-line treatment of advanced CRC. After bevacizumab was approved in 2004, the trial was amended to include bevacizumab in all arms. The addition of 
Table 5 Capecitabine with bevacizumab

\begin{tabular}{|c|c|c|c|c|c|c|}
\hline References & $\begin{array}{l}\text { Study phase, } \\
\text { patients enrolled }\end{array}$ & Regimen & Response rate $(\%)$ & $\begin{array}{l}\text { Median } \\
\text { progression- } \\
\text { free survival }\end{array}$ & $\begin{array}{l}\text { Median overall } \\
\text { survival }\end{array}$ & Safety, tolerability \\
\hline $\begin{array}{l}\text { Giantonio } \\
\text { et al. } \\
{[34]}\end{array}$ & Phase III; $N=829$ & $\begin{array}{l}\text { FOLFOX-4 with B; } \\
\text { FOLFOX-4; B alone }\end{array}$ & $\begin{array}{c}\text { ORR: } 22.7,8.6,3.3 \% \\
\text { (FOLFOX-4 with B, } \\
\text { FOLFOX-4, B alone) }\end{array}$ & $\begin{array}{l}\text { 7.3, } 4.7 \\
2.7 \text { months } \\
\text { (FOLFOX- } \\
4 \text { with B, } \\
\text { FOLFOX- } \\
\text { 4, B alone) }\end{array}$ & $\begin{array}{l}\text { Median survival } \\
\text { duration: } 12.9, \\
10.8, \\
10.2 \text { months } \\
\text { (FOLFOX-4 } \\
\text { with B, } \\
\text { FOLFOX-4, B } \\
\text { alone) }\end{array}$ & $\begin{array}{l}\text { Grade } 3 / 4 \text { toxicities } \\
\text { increased } 14 \% \text { with } \\
\text { FOLFOX-4 + B; grade } \\
\text { 3/4 bleeding associated } \\
\text { with B }\end{array}$ \\
\hline $\begin{array}{l}\text { Hochster } \\
\text { et al. } \\
\text { [35] }\end{array}$ & $\begin{array}{l}\text { Sequentially } \\
\text { randomized phase } \\
\text { II, TREE- } 1 \text {, } \\
N=150 ; \text { TREE- } \\
2, N=223 ; \\
\text { Primary end } \\
\text { point = grade } 3 / 4 \\
\text { AEs }\end{array}$ & $\begin{array}{l}\text { TREE } 1 \text { : modified } \\
\text { FOLFOX-6 (Ox } 85 \mathrm{mg} / \\
\mathrm{m}^{2} \mathrm{IV}+\mathrm{LV} 350 \mathrm{mg} \mathrm{IV} \\
\text { over } 2 \mathrm{~h}+5 \text {-FU } 400 \mathrm{mg} / \\
\mathrm{m}^{2} \mathrm{IV} \text { bolus }+2,400 \mathrm{mg} / \\
\mathrm{m}^{2} \text { infusion over } 46 \mathrm{~h} \text { ) } \\
\text { every } 2 \text { weeks or bFOL } \\
\text { (Ox } 85 \mathrm{mg} / \mathrm{m}^{2} \mathrm{IV} \text { on days } \\
1 \text { and } 15+\mathrm{LV} 20 \mathrm{mg} / \mathrm{m}^{2} \\
\text { IV over } 10-20 \mathrm{~min} \\
\text { followed by } 5 \text {-FU } \\
500 \mathrm{mg} / \mathrm{m}^{2} \text { IV push on } \\
\text { days } 1,8 \text {, and } 15 \text { every } \\
4 \text { weeks) or CapeOx (Ox } \\
130 \mathrm{mg} / \mathrm{m}^{2} \text { IV on day } 1 \\
\text { and C } 1,000 \mathrm{mg} / \mathrm{m}^{2} \text { orally } \\
\text { bid on days } 1-15 \text { every } \\
3 \text { weeks TREE- } 2: \text { same } 3 \\
\text { arms }+ \text { B before CT at } \\
5 \mathrm{mg} / \mathrm{kg} \text { IV every } \\
2 \text { weeks (FOLFOX and } \\
\text { bFOL regimens) or } \\
7.5 \mathrm{mg} / \mathrm{kg} \mathrm{IV} \mathrm{every} \\
3 \text { weeks (CapeOx); C } \\
\text { dose reduced to } \\
1,700 \mathrm{mg} / \mathrm{m}^{2} / \text { day }\end{array}$ & $\begin{array}{l}\text { TREE-1: ORR: } 41,20, \\
\text { 27\% (modified } \\
\text { FOLFOX-6, bFOL, } \\
\text { CapeOx) TREE-2: } 52, \\
\text { 39, 46\% (modified } \\
\text { FOLFOX-6, bFOL, } \\
\text { CapeOx) }\end{array}$ & & $\begin{array}{l}\text { TREE-1: 19.2, } \\
\text { 17.9, } \\
\text { 17.2 months } \\
\text { (modified } \\
\text { FOLFOX-6, } \\
\text { bFOL, } \\
\text { CapeOx) } \\
\text { TREE-2: 26.1, } \\
20.4, \\
24.6 \text { months } \\
\text { (modified } \\
\text { FOLFOX-6, } \\
\text { bFOL, } \\
\text { CapeOx) }\end{array}$ & $\begin{array}{l}\text { TREE-1: Grade 3/4 AEs } \\
\text { during first } 12 \text { weeks: 59, } \\
\text { 36, 67\% (modified } \\
\text { FOLFOX-6, bFOL, } \\
\text { CapeOx); CapeOx } \\
\text { toxicity in TREE-1 } \\
\text { included grade 3/4 } \\
\text { diarrhea (31\%) and } \\
\text { dehydration (27\%) } \\
\text { TREE-2: 59, 51, 56\% } \\
\text { (modified FOLFOX-6, } \\
\text { bFOL, CapeOx) }\end{array}$ \\
\hline
\end{tabular}

FOLFOX-4 = oxaliplatin $85 \mathrm{mg} / \mathrm{m}^{2}$ on day 1 only given as a 2 -h infusion concurrent with $\mathrm{LV}$ at $200 \mathrm{mg} / \mathrm{m}^{2} / \mathrm{day}$ followed by bolus 5 -FU $400 \mathrm{mg} / \mathrm{m}^{2} / \mathrm{day}$ and a 22 -h infusion of 5 -FU $600 \mathrm{mg} / \mathrm{m}^{2} /$ day, repeated for two consecutive days every 2 weeks; FOLFOX-6 = oxaliplatin $100 \mathrm{mg} / \mathrm{m}^{2}$ on day $1, \mathrm{LV}$ $400 \mathrm{mg} / \mathrm{m}^{2}$ 2-h infusion, then $5-\mathrm{FU} 400 \mathrm{mg} / \mathrm{m}^{2}$ IV bolus, then $2,400-3,000 \mathrm{mg} / \mathrm{m}^{2}$ 46-h infusion, every 2 weeks

AEs adverse events, $B$ bevacizumab, $b F O L$ oxaliplatin plus bolus 5-FU/LV, $C$ capecitabine, CapeOx capecitabine plus oxaliplatin, $C T$ chemotherapy, FOLFOX fluorouracil/leucovorin/oxaliplatin, $I V$ intravenous, $L V$ leucovorin, ORR overall response rate, $O x$ oxaliplatin, TREE Three Regimens of Eloxatin Evaluation

bevacizumab lengthened OS in the three different regimens, as seen in TREE-2 compared with TREE-1 (Table 5). In the final toxicity analysis of TREE-2, bFOL appeared to have the greater toxicity: efficacy ratio, with a $30 \%$ incidence of grade 3/4 diarrhea; for FOLFOX, the incidence was $11 \%$ and for CapeOx, $17 \%$.

Similarly, as previously discussed, the BICC-C trial also has demonstrated benefit with the addition of bevacizumab to chemotherapy [27]. In another phase III trial, addition of bevacizumab to an oxaliplatin-based regimen such as XELOX or FOLFOX-4 demonstrated improvement in PFS (9.4 vs. 8 months; $P=0.0023$ ) with no difference in RRs and OS [36]. ACCORD is a prospective, non-comparative phase II study randomizing 145 patients to XELIRI (capecitabine/irinotecan), or FOLFIRI plus bevacizumab. The study demonstrated a 6-month objective RR of $54 \%$ in the XELIRI arm and 59\% in the FOLFIRI arm. Median PFS was 9.3 and 9.0 months, respectively, and median OS was 23.0 and 23.4 months, respectively, in the XELIRI and FOLFIRI arms. Clinical AEs generally were similar, acceptable, and manageable in both treatment arms. This randomized, non-comparative trial demonstrated that bevacizumab plus XELIRI and bevacizumab plus FOLFIRI are active and similarly effective treatment options for patients with mCRC [37].

Although adding bevacizumab therapy appears to improve multiple efficacy points compared with cytotoxic therapy alone, it is important to remember that the use of bevacizumab with capecitabine combinations is based on retrospective, cross-trial comparisons and phase II trial data, but should be validated further in randomized phase III trials. 
EGFR gene is upregulated in $60-80 \%$ of CRC patients, and over expression of the gene is associated with poor survival. EGFR signaling pathways play a major role in cell differentiation, proliferation, migration, angiogenesis, and apoptosis. Two EGFR-directed antibodies have been approved for the treatment of patients with advanced colorectal carcinoma: cetuximab, a chimeric antibody, and panitumumab, a fully humanized monoclonal antibody [38, 39]. Phase III, CRYSTAL trial (Cetuximab Combined with Irinotecan in First-Line Therapy for Metastatic Colorectal Cancer) demonstrated improvement in PFS (8.9 vs. 8 months) and RR (46.9 vs. $38.7 \%)$ with addition of cetuximab to irinotecan in front-line setting [40]. Only improvement in RRs (22.9 vs. $10.8 \%$ ) were noted in the second-line setting based on phase III data by Cunningham et al. [38]. Similarly, improvement in RR (45.6 vs. 35.7\%) was noted with the addition of cetuximab to FOLFOX in a phase II OPUS (Oxaliplatin and Cetuximab in First-Line Treatment of mCRC) trial [41].

Borner et al. conducted a multicenter, randomized, phase II study comparing XELOX with the combination of
XELOX plus cetuximab. This trial demonstrated an increase in RRs without a significant increase in toxicity, except for an increased frequency of skin toxicity in the arm with cetuximab. Treatment was continued up to a maximum of six cycles or until disease progression (Table 6) [42].

To date, there are limited published data on the XELIRI/ cetuximab regimen. Preliminary results from two phase II trials of combinations of cetuximab with irinotecan plus capecitabine demonstrate that this combination has promising clinical activity. Heinemann et al. have demonstrated an overall RR of $42 \%$, with an overall disease control rate of $91 \%$ (Table 6) [43, 44]. Cartwright et al. [45] have demonstrated in 53 evaluable patients that $5.7 \%$ had complete responses, $37.7 \%$ had partial responses, and $43.4 \%$ had stable disease with median survival of 20.5 months, with $45.7 \%$ of patients remaining alive at the time of the report (Table 6).

Although we are optimistic that cetuximab with a XELOX or XELIRI combination will prove to be beneficial, we await the results of ongoing phase III trials before routinely applying these phase II results.

Table 6 Capecitabine with EGFR inhibitors

\begin{tabular}{|c|c|c|c|c|c|c|}
\hline References & $\begin{array}{l}\text { Study phase, } \\
\text { patients enrolled }\end{array}$ & Regimen & Response rate $(\%)$ & $\begin{array}{l}\text { Median } \\
\text { progression-free } \\
\text { survival }\end{array}$ & $\begin{array}{l}\text { Median } \\
\text { overall } \\
\text { survival }\end{array}$ & Safety, tolerability \\
\hline $\begin{array}{l}\text { Borner et al. } \\
\text { [42] }\end{array}$ & Phase II, $N=74$ & $\begin{array}{l}\text { Ox } 130 \mathrm{mg} / \mathrm{m}^{2} / \text { day }+\mathrm{C} \\
1,000 \mathrm{mg} / \mathrm{m}^{2} \text { bid days } 1-14 \\
\text { every } 3 \text { weeks alone } \\
(\text { XELOX) or XELOX }+\mathrm{C} \\
400 \mathrm{mg} / \mathrm{m}^{2} \text { followed by } \\
\text { weekly infusions of } \\
250 \mathrm{mg} / \mathrm{m}^{2}\end{array}$ & $\begin{array}{l}\text { Partial RRs: } 14,41 \% \\
\text { (XELOX vs. C); } \\
\text { SD: } 62,35 \% \\
\text { (XELOX vs. C) }\end{array}$ & $\begin{array}{l}\text { Median: } 5.8 \text { vs. } \\
7.2 \text { months } \\
\text { (XELOX vs. C) }\end{array}$ & $\begin{array}{l}\text { Median: } 16.5 \\
\text { vs. } 20.5 \\
\text { months } \\
\text { (XELOX } \\
\text { vs. C) }\end{array}$ & $\begin{array}{l}\mathrm{C} \text { led to skin rash } \\
\text { in } 65 \%\end{array}$ \\
\hline $\begin{array}{l}\text { Heinemann } \\
\text { et al. [43, } \\
44]\end{array}$ & Phase II, $N=92$ & $\begin{array}{l}\text { C } 800 \mathrm{mg} / \mathrm{m}^{2} \text { bid on days } \\
1-14+\text { irinotecan } 200 \mathrm{mg} / \\
\mathrm{m}^{2} \text { on day } 1 \text { (XELIRI) or C } \\
1,000 \mathrm{mg} / \mathrm{m}^{2} \text { bid days } \\
1-14+\text { Ox } 130 \mathrm{mg} / \mathrm{m}^{2} \text { on } \\
\text { day } 1 \text { (XELOX) }\end{array}$ & $\begin{array}{l}\text { ORR: } 42 \text { vs. } 66 \% \text {; DCR } \\
\text { (ORR + SD): } 91 \text { vs. } \\
\text { 93\% (XELIRI vs. } \\
\text { XELOX) }\end{array}$ & & & $\begin{array}{l}\text { Most common grade } \\
\text { 3/4 toxicities: } \\
\text { diarrhea: } 20.9 \text { vs. } \\
\text { 19.5\%; skin } \\
\text { toxicity: } 16.3 \text { vs. } \\
\text { 26.8\%; } \\
\text { neurotoxicity: } 2.3 \\
\text { vs. } 17.1 \% \text {; } \\
\text { leucopenia: } 9.3 \text { vs. } \\
\text { 4.9\% (XELIRI vs. } \\
\text { XELOX) }\end{array}$ \\
\hline $\begin{array}{l}\text { Cartwright } \\
\text { et al. [45] }\end{array}$ & $\begin{array}{l}\text { Phase II, } N=70 \\
53 \text { evaluable }\end{array}$ & 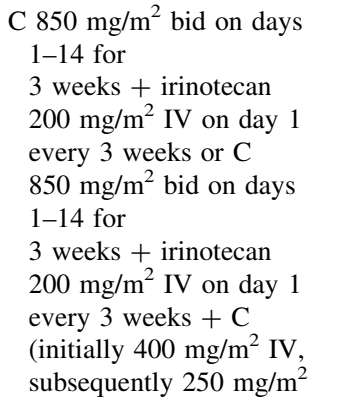 & $\begin{array}{l}\text { CR: } 5.7 \% \text {; PR: } 37.7 \% \text {; } \\
\text { ORR: } 43.4 \% \text { (PP), 34\% } \\
\text { (ITT) DCR: } 86.8 \% \\
\text { (PP), 69\% (ITT) }\end{array}$ & $\begin{array}{l}\text { TTP: } 8.1 \text { months } \\
\text { TTR: } \\
1.6 \text { months }\end{array}$ & $\begin{array}{l}\text { Median: } \\
20.5 \text { months }\end{array}$ & $\begin{array}{l}\text { Most common grade } \\
\text { 3/4 toxicities: } \\
\text { diarrhea, } \\
\text { neutropenia, and } \\
\text { nausea/vomiting }\end{array}$ \\
\hline
\end{tabular}

$C$ capecitabine, $C R$ complete response, $D C R$ disease control rate, EGFR epidermal growth factor receptor, $I T T$ intent-to-treat, $I V$ intravenous, $O R R$ overall response rate, $O x$ oxaliplatin, $P P$ per protocol, $P R$ partial response, $R R$ response rate, $S D$ stable disease, $T T P$ time to progression, $T T R$ time to response, $X E L O X$ capecitabine plus oxaliplatin 
Capecitabine in the adjuvant setting

The benefits of 5-FU-based adjuvant chemotherapy in reducing the risk of relapse and prolonging survival in patients with surgically resected CRC are well established, particularly in stage III disease [46-54]. In a phase III trial [Xeloda in Adjuvant Colon Cancer Therapy (X-ACT)], capecitabine was compared to Mayo Clinic 5-FU/LV regimen as surgical adjuvant treatment in stage III CRC (Table 7) [55]. Initially, there was a trend toward superior disease-free survival (DFS) noted for the capecitabine arm compared to 5-FU/LV $(P=0.05)$. However, the difference did not hold true at the 3-year follow-up with loss of statistical difference between the arms (64.2 vs. $60.6 \%$; $P=0.12)$. Relapse-free survival was longer for the capecitabine arm as compared to 5-FU/LV $(P=0.04)$, though OS did not differ significantly $(P=0.07)$. Overall, there was a significantly lower incidence of neutropenia and stomatitis and lower rates of nausea, vomiting, alopecia, and diarrhea in the setting of adjuvant treatment with capecitabine. However, the incidence of grade 3 HFS was significantly higher with capecitabine than with 5-FU/LV. This trial demonstrates that capecitabine is at least equivalent to the Mayo Clinic regimen of 5-FU/LV in the surgical adjuvant treatment of CRC [55].
The success of multiagent combination therapy in the treatment of $\mathrm{mCRC}$ has provided a compelling basis for testing such regimens in the adjuvant setting. Two large trials have demonstrated that the addition of oxaliplatin to 5-FU/LV has been shown to prolong DFS significantly in patients with stage II/III CRC, with a reduction in the risk of recurrence of $23 \%$ in the group given 5 -FU/LV plus oxaliplatin compared with 5-FU/LV alone [56, 57].

These developments led to an international, randomized, phase III trial (XELOXA) in which 1,886 patients were randomized to adjuvant treatment with either XELOX or IV bolus 5-FU/LV given by 1 of 2 regimens (Mayo Clinic or Roswell Park). Bolus 5-FU/LV was chosen for comparison as it was standard at the time of study initiation. Both safety and efficacy were assessed in this study, though efficacy data were reported only in an abstract form indicating a benefit in DFS for XELOX [58].

Most treatment-related AEs occurred at similar rates in both treatment arms. However, patients receiving capecitabine plus oxaliplatin experienced less all-grade diarrhea and alopecia, and more neurosensory toxicity, vomiting, and HFS than with 5-FU/LV. Compared with the Mayo regimen, capecitabine plus oxaliplatin demonstrated fewer grade 3/4 hematologic AEs and more grade 3/4 gastrointestinal AEs. Compared with the Roswell Park regimen,

Table 7 Capecitabine in the adjuvant setting

\begin{tabular}{|c|c|c|c|c|c|}
\hline References & Patients enrolled $(N)$ & Regimen & Disease-free survival & $\begin{array}{l}\text { Median } \\
\text { survival }\end{array}$ & Safety, tolerability \\
\hline $\begin{array}{l}\text { Twelves } \\
\text { et al. } \\
\text { [54] } \\
\text { (X-ACT) }\end{array}$ & $\begin{array}{l}N=1,987 \text { with } \\
\text { resected stage III } \\
\text { CRC }\end{array}$ & $\begin{array}{l}\mathrm{C} 1,250 \mathrm{mg} / \mathrm{m}^{2} \text { bid on days } 1-14 \\
\text { every } 21 \text { days or six cycles of } \\
\text { rapid IV infusion of LV } 20 \mathrm{mg} / \\
\mathrm{m}^{2} \text { followed immediately by IV } \\
\text { bolus of } 5 \text {-FU } 425 \mathrm{mg} / \mathrm{m}^{2} \text { on } \\
\text { days } 1-5 \text { every } 28 \text { days }\end{array}$ & $\begin{array}{l}\text { C group } \geq 5 \text {-FU } \\
\text { group; relapse-free } \\
\text { survival ( } 3 \text {-year } \\
\text { rate): } 65.5 \text { vs. } \\
61.9 \% \text { (C vs. } 5 \text {-FU/ } \\
\text { LV) }\end{array}$ & $\begin{array}{l}\text { OS } \\
\text { (3 years) } \\
81.3 \text { vs. } \\
77.6 \%(\mathrm{C} \\
\text { vs. } 5 \text {-FU/ } \\
\text { LV) }\end{array}$ & $\begin{array}{l}\text { Less neutropenia, stomatitis, } \\
\text { nausea, vomiting, alopecia, and } \\
\text { diarrhea, but more HFS with C } \\
\text { vs. 5-FU/LV }\end{array}$ \\
\hline $\begin{array}{l}\text { Schmoll } \\
\text { et al. } \\
\text { [58] }\end{array}$ & $\begin{array}{l}N=1,864 \text { (safety } \\
\text { population) who } \\
\text { have undergone } \\
\text { surgery for stage III } \\
\text { colon carcinoma }\end{array}$ & $\begin{array}{l}\text { XELOX (IV Ox }+ \text { C, } 3 \text {-week } \\
\text { cycle for } 8 \text { cycles) or IV bolus } \\
\text { 5-FU/LV administered as Mayo } \\
\text { Clinic or RP }\end{array}$ & & & $\begin{array}{l}\text { Similar rates in both arms; } \\
\text { XELOX patients had less } \\
\text { diarrhea and alopecia; more } \\
\text { neurosensory toxicity, vomiting, } \\
\text { and HFS; compared with Mayo, } \\
\text { XELOX associated with fewer } \\
\text { grade } 3 / 4 \text { heme AEs and more } \\
\text { grade } 3 / 4 \text { GI AEs; compared } \\
\text { with RP, XELOX associated } \\
\text { with fewer grade } 3 / 4 \text { GI AEs and } \\
\text { more grade } 3 / 4 \text { hematologic } \\
\text { AEs; higher rate of grade } 3 / 4 \\
\text { neurosensory toxicity and grade } \\
3 \text { HFS with XELOX; treatment- } \\
\text { related mortality at } 28 \text { days from } \\
\text { last study dose: } 0.6 \% \text { in both the } \\
\text { groups }\end{array}$ \\
\hline
\end{tabular}

AEs adverse events, $B$ bevacizumab, bid twice a day, $C$ capecitabine, $C R C$ colorectal cancer, $H F S$ hand foot syndrome, 5-FU fluorouracil, $G I$ gastrointestinal, HFS hand-foot syndrome, $I V$ intravenous, $L V$ leucovorin, $O x$ oxaliplatin, $O S$ overall survival, $R P$ Roswell Park regimen, $X$-ACT Xeloda in Adjuvant Colon Cancer Therapy, XELOX capecitabine plus oxaliplatin 
capecitabine plus oxaliplatin demonstrated fewer grade 3/4 gastrointestinal AEs and more grade 3/4 hematologic AEs. As expected, grade 3/4 neurosensory toxicity and grade 3 HFS were higher with capecitabine plus oxaliplatin. It was concluded that capecitabine plus oxaliplatin has a manageable tolerability profile in the adjuvant setting [58]. The 3-year DFS, as reported at the 2009 European Cancer Conference, demonstrated 71\% 3-year DFS for patients on the XELOX arm, compared with $67 \%$ for the 5-FU/LV arm (hazard ratio $=0.80 ; P=0.0045$ ) [59]. In addition, an update presented at the 2010 Gastrointestinal Cancers Symposium demonstrated that these differences in DFS demonstrated similar advantage for XELOX over 5-FU/LV for both patients $>70$ years and $<70$ years of age [60]. It is too early to detect a survival difference, and further followup is needed. These data demonstrate that XELOX can be considered as an acceptable alternative for patients with resectable stage III CRC in the adjuvant setting. There are no comparative studies between XELOX, infusional 5-FU, and oxaliplatin available at this date.

\section{Pharmacoeconomics and patient considerations}

Cost comparisons of capecitabine monotherapy versus bolus 5-FU/LV (Mayo Clinic regimen) show that the higher acquisition cost of capecitabine is partially or completely offset by costs associated with treating toxicity and the higher administration costs of IV 5-FU/LV in both the metastatic [61, 62] and adjuvant [63-66] settings.

Cost analyses of XELOX ( \pm bevacizumab) versus FOLFOX ( \pm bevacizumab) show the same trends. A comparison of the expected costs of XELOX and FOLFOX-4 from the United States third-party payer and societal perspectives during the study period of the randomized NO16966 phase III trial showed that patients receiving FOLFOX-4 required approximately 15-20 more office visits for drug administration and spent more hours in office and clinic visits than patients treated with XELOX (22-27 vs. 7-9 visits). The total direct medical costs were comparable between XELOX and FOLFOX-4 [67, 68].

A cost-minimization analysis found that the average cost of chemotherapy per cycle per patient was significantly lower with capecitabine plus oxaliplatin than with FOLFOX-6. In addition, the analysis determined that overall clinic/hospital resource consumption was markedly reduced compared with FOLFOX-6 [69]. Finally, a retrospective database analysis reported a substantial savings associated with capecitabine plus oxaliplatin compared with 5-FU/LV/oxaliplatin chemotherapy [70]. Together, these prospective pharmacoeconomic and cost analyses, along with the retrospective claims database analysis, provide a consistent view that capecitabine-based therapy is associated with a favorable cost comparison versus infusional 5-FU-based therapy in patients with CRC.

Available quality-of-life data suggest that there are no differences between capecitabine and 5-FU-based regimens [71, 72]. A study by Liu et al. [73] suggests that patients prefer oral chemotherapy, provided that efficacy is not compromised. Formal patient preference studies suggest that oral capecitabine is preferred over IV 5-FU regimens and that patient preference is influenced by tolerability as well as route of administration [74, 75]. Even though oral chemotherapy comes with advantages such as reduced frequency of clinic visits, flexibility of taking it at home and increased control/participation in care, it does come with disadvantages such as compliance, need for extensive patient education and awareness of bioavailability and drug interactions [76].

Patients find oral chemotherapy more convenient than IV therapy [77]. In terms of convenience, XELOX requires fewer planned office visits than FOLFOX-4 or FOLFOX-6, because oxaliplatin is administered every 3 weeks and capecitabine is taken orally. Medical resource use data from the NO16966 trial demonstrated that the need for drug administration visits and central venous access are reduced with XELOX versus FOLFOX-4 despite the addition of IV agents, e.g., oxaliplatin and bevacizumab [70]. Functional Assessment of Chronic Illness Therapy Chemotherapy Convenience and Satisfaction Questionnaire data from the ML16987 trial showed that patients treated with capecitabine plus oxaliplatin waste less of their free time and are more likely to be satisfied with treatment [71].

\section{Future directions}

Another common use of capecitabine is with radiation therapy in the preoperative management of rectal cancer. There are several phase II trials supporting its role in this setting [78, 79]. We await the results of a phase III study of preoperative chemo radiotherapy comprising radiation and either capecitabine or 5-FU with or without oxaliplatin in patients with resectable rectal cancer. This trial has recently completed accrual, and results should help to define capecitabine's role in this setting [80].

\section{Conclusions}

The evolution of fluorpyrimidine regimens and the introduction of new cytotoxic and targeted agents have led to important changes in how CRC is treated. Singleagent capecitabine, an oral pro-drug of 5-FU, has been shown to be equivalent to IV 5-FU in mCRC as well as 
in the adjuvant setting. Capecitabine combined with oxaliplatin also has proven to be as effective as oxaliplatin 5-FU-containing combinations in the treatment of mCRC. The primary distinction between the two regimens is related to differences in toxicity and ease of administration. Capecitabine plus irinotecan combinations in this setting have produced more variable results, with some dose regimens resulting in excessive toxicity. At this time, combination treatment with irinotecan and capecitabine generally is not recommended, though there are recent data (without celecoxib) that have been more promising.

In addition, based on recent positive phase III data, capecitabine in combination with oxaliplatin appears to be an acceptable treatment option for patients in the surgical adjuvant setting. These data were recently presented at two international meetings and approval is expected later in the year $[58,59]$. The use of capecitabine in conjunction with radiation therapy for the treatment of rectal cancer awaits the results of a definitive phase III trial to further define its role in this setting.

The choice of capecitabine over IV 5-FU primarily is based on differences in toxicity and ease of administration. In general, there is less stomatitis and neutropenia with capecitabine-containing regimens, with the trade-off of more HFS reactions and diarrhea. Using capecitabine in combination therapy avoids the use of long-term indwelling catheters, infusion pumps, and their complications, and requires fewer patient visits to the clinic. In terms of direct costs, capecitabine plus oxaliplatin appears to be cost-neutral compared with 5-FU/LV/oxaliplatin. However, capecitabine plus oxaliplatin is associated with improved indirect costs and patient convenience, which may improve patient compliance and satisfaction with treatment. Capecitabine is an acceptable alternative to IV 5-FU in the treatment of CRC in most settings. The primary exceptions would be in combination with irinotecan, in which case less toxicity is observed with infusion of 5-FU as opposed to capectiabine. The other exception would be in the case of patients on long-term anticoagulation with warfarin-the intermittent schedule utilized with capecitabine and its interaction with warfarin can cause difficulty with maintaining safe and effective anticoagulation.

Conflict of interest The author declares that Editorial assistance was provided by Insight Medical Communications Inc., New York, NY, which was financially supported by Roche Laboratories, Nutley, NJ, USA and Genentech, South San Francisco, California, USA.

Open Access This article is distributed under the terms of the Creative Commons Attribution Noncommercial License which permits any noncommercial use, distribution, and reproduction in any medium, provided the original author(s) and source are credited.

\section{References}

1. Heidelberger C, Chaudhuri N, Danenberg P et al (1957) Fluorinated pyrimidines, a new class of tumour-inhibitory compounds. Nature 179:663-666

2. Rich TA (1997) Irradiation plus 5-fluorouracil: cellular mechanisms of action and treatment schedules. Semin Radiat Oncol 7:267-273

3. Smalley S, Kimler B, Evans R et al (1992) Heterogeneity of 5 -fluorouracil radiosensitivity modulation in cultured mammalian cell lines. Int J Radiat Oncol Biol Phys 24:519-525

4. Drewinko B, Yang LY (1985) Cellular basis for the inefficacy of 5-FU in human colon carcinoma. Cancer Treat Rep 69:1391-1398

5. Calabro-Jones PM, Byfield JE, Ward JF et al (1982) Time-dose relationships for 5-fluorouracil cytotoxicity against human epithelial cancer cells in vitro. Cancer Res 42:4413-4420

6. Byfield JE, Calabro-Jones P, Klisak I et al (1982) Pharmacologic requirements for obtaining sensitization of human tumor cells in vitro to combined 5-fluorouracil or ftorafur and $\mathrm{X}$ rays. Int $\mathrm{J}$ Radiat Oncol Biol Phys 8:1923-1933

7. Meta-analysis Group In Cancer (1998) Efficacy of intravenous continuous infusion of fluorouracil compared with bolus administration in advanced colorectal cancer. J Clin Oncol 16:301-308

8. Meta-analysis Group In Cancer (1998) Toxicity of fluorouracil in patients with advanced colorectal cancer: Effect of administration schedule and prognostic factors. J Clin Oncol 16:3537-3541

9. Walko CM, Lindley C (2005) Capecitabine: a review. Clin Ther 27:23-44

10. Miwa M, Ura M, Nishida M et al (1998) Design of a novel oral fluoropyrimidine carbamate, capecitabine, which generates 5 -fluorouracil selectively in tumours by enzymes concentrated in human liver and cancer tissue. Eur J Cancer 34:1274-1281

11. Schüller J, Cassidy J, Dumont E et al (2000) Preferential activation of capecitabine in tumor following oral administration to colorectal cancer patients. Cancer Chemother Pharmacol 45:291-297

12. Hoff PM, Cassidy J, Schmoll HJ (2001) The evolution of fluoropyrimidine therapy: from intravenous to oral. Oncologist 6(Suppl 4):3-11

13. Budman DR, Meropol NJ, Reigner B et al (1998) Preliminary studies of a novel oral fluoropyrimidine carbamate: capecitabine. J Clin Oncol 16:1795-1802

14. Mackean MJ, Planting AS, Twelves C et al (1998) A phase I and pharmacological study of intermittent twice-daily oral therapy with capecitabine in patients with advanced and/or metastatic cancer. J Clin Oncol 16:2977-2985

15. Cassidy J, Dirix L, Bissett D et al (1998) A phase I study of capecitabine in combination with oral leucovorin in patients with intractable solid tumors. Clin Cancer Res 4:2755-2761

16. Van Cutsem E, Findlay M, Osterwalder B et al (2000) Capecitabine, an oral fluoropyrimidine carbamate with substantial activity in advanced colorectal cancer: results of a randomized phase II study. J Clin Oncol 18:1337-1345

17. Hoff PM, Ansari R, Batist G et al (2001) Comparison of oral capecitabine versus intravenous fluorouracil plus leucovorin as first-line treatment in 605 patients with metastatic colorectal cancer: results of a randomized phase III study. J Clin Oncol 19:2282-2292

18. Van Cutsem E, Twelves C, Cassidy J et al (2001) Oral capecitabine compared with intravenous fluorauracil plus leucovorin in patients with metastatic colorectal cancer: results of a large phase III study. J Clin Oncol 19:4097-4106

19. Van Cutsem E, Hoff PM, Harper P et al (2004) Oral capecitabine versus intravenous 5-fluorouracil and leucovorin: integrated efficacy data and novel analyses from two large, randomised, phase III trials. Br J Cancer 90:1190-1197 
20. Sawada N, Kondoh K, Mori K (2007) Enhancement of capecitabine efficacy by oxaliplatin in human colorectal and gastric cancer xenografts. Oncol Rep 18:775-778

21. Díaz-Rubio E, Evans TR, Tabernero J et al (2002) Capecitabine (Xeloda) in combination with oxaliplatin: a phase I, dose-escalation study in patients with advanced or metastatic solid tumors. Ann Oncol 13:558-565

22. Cassidy J, Tabernero J, Twelves C et al (2004) XELOX (capecitabine plus oxaliplatin): active first-line therapy for patients with metastatic colorectal cancer. J Clin Oncol 22:2084-2091

23. Cassidy J, Clarke S, Díaz Rubio E et al (2008) A randomized phase III study of capecitabine plus oxaliplatin (XELOX) versus fluorouracil/folinic acid plus oxaliplatin (FOLFOX-4) as first-line therapy for metastatic colorectal cancer. J Clin Oncol 26:2006-2012

24. Rothenberg ML, Cox JV, Butts C et al (2008) Capecitabine plus oxaliplatin (XELOX) versus 5-fluorouracil/folinic acid plus oxaliplatin (FOLFOX-4) as second-line therapy in metastatic colorectal cancer: a randomized phase III noninferiority study. Ann Oncol 19:1720-1726

25. Ducreux M, Bennouna J, Hebbar M et al (2007) Efficacy and safety findings from a randomized phase III study of capecitabine (X) + oxaliplatin (O) (XELOX) versus infusional 5- FU/ $\mathrm{LV}+\mathrm{O}$ (FOLFOX-6) for metastatic colorectal cancer (MCRC). J Clin Oncol 25(18S):170s (abstract 4029)

26. Arkenau H-T, Arnold D, Cassidy J et al (2008) Efficacy of oxaliplatin plus capecitabine or infusional fluorouracil/leucovorin in patients with metastatic colorectal cancer: a pooled analysis of randomized trials. J Clin Oncol 26:5910-5917

27. Fuchs CS, Marshall J, Mitchell E et al (2007) Randomized, controlled trial of irinotecan plus infusional, bolus, or oral fluoropyrimidines in first-line treatment of metastatic colorectal cancer: results from the BICC-C Study. J Clin Oncol 25:4779-4786

28. Köhne $\mathrm{CH}$, De Greve J, Hartmann JT et al (2008) Irinotecan combined with infusional 5-fluorouracil/folinic acid or capecitabine plus celecoxib or placebo in the first-line treatment of patients with metastatic colorectal cancer. EORTC study 40015. Ann Oncol 19:920-926

29. Koopman M, Antonini NF, Douma J et al (2007) Sequential versus combination chemotherapy with capecitabine, irinotecan, and oxaliplatin in advanced colorectal cancer (CAIRO): a phase III randomised controlled trial. Lancet 370:135-142

30. Garcia Alfonso P, Méndez M, Muñoz A, et al (2008) A phase II trial of capecitabine and irinotecan in a biweekly schedule in patients with previously untreated advanced colorectal cancer (ACRC). In: Presented at the American Society of Clinical Oncology 2008 Gastrointestinal Cancers Symposium, January 25-27, 2008, Orlando, FL (abstract 481)

31. Kerbel R, Folkman J (2002) Clinical translation of angiogenesis inhibitors. Nat Rev Cancer 2:727-739

32. Tokunaga T, Oshika Y, Abe Y et al (1998) Vascular endothelial growth factor (VEGF) mRNA isoform expression pattern is correlated with liver metastasis and poor prognosis in colon cancer. Br J Cancer 77:998-1002

33. Hurwitz H, Fehrenbacher L, Novotny W et al (2004) Bevacizumab plus irinotecan, fluorouracil, and leucovorin for metastatic colorectal cancer. N Engl J Med 350:2335-2342

34. Giantonio B, Catalano P, Meropol N et al (2007) Bevacizumab in combination with oxaliplatin, fluorouracil, and leucovorin (FOLFOX4) for previously treated metastatic colorectal cancer: results from the Eastern Cooperative Oncology Group Study E3200. J Clin Oncol 25:1539-1544

35. Hochster H, Hart LL, Ramanathan RK (2008) Safety and efficacy of oxaliplatin and fluoropyrimidine regimens with or without bevacizumab as first-line treatment of metastatic colorectal cancer: results of the TREE study. J Clin Oncol 26:3523-3529
36. Saltz LB, Clarke S, Díaz-Rubio E et al (2008) Bevacizumab in combination with oxaliplatin-based chemotherapy as first-line therapy in metastatic colorectal cancer: a randomized phase III study. J Clin Oncol 26(12):2013-2019

37. Ducreux M, Adenis A, Pignon JP et al (2009) Efficacy and safety of bevacizumab-based combination regimens in patients with metastatic colorectal cancer: final results from a randomised phase II study of bevacizumab + FOLFIRI vs. bevacizumab + XELIRI (FNCLCC ACCORD 13/0503 study). Eur J Cancer Suppl 7(2):347

38. Cunningham D, Humblet Y, Siena S et al (2004) Cetuximab monotherapy and cetuximab plus irinotecan in irinotecanrefractory metastatic colorectal cancer. N Engl J Med 351:337345

39. Van Cutsem E, Peeters M, Siena S et al (2007) Open-label phase III trial of panitumumab plus best supportive care compared with best supportive care alone in patients with chemotherapyrefractory metastatic colorectal cancer. J Clin Oncol 25:1658-1664

40. Van Cutsem E, Nowacki M, Lang I et al (2007) Randomized phase III study of irinotecan and 5-FU/FA with or without cetuximab in the first-line treatment of patients with metastatic colorectal cancer (mCRC): the CRYSTAL trial. J Clin Oncol 25(18S): 164s (abstract 4000)

41. Bokemeyer C, Bondarenko I, Makhson A et al (2009) Fluorouracil, leucovorin, and oxaliplatin with and without cetuximab in the first-line treatment of metastatic colorectal cancer. J Clin Oncol 10:663-671

42. Borner M, Koeberle D, Von Moos R, for the Swiss Group for Clinical Cancer Research (SAKK) et al (2008) Adding cetuximab to capecitabine plus oxaliplatin (XELOX) in first-line treatment of metastatic colorectal cancer: a randomized phase II trial of the Swiss Group for Clinical Cancer Research SAKK. Ann Oncol 19:1288-1292

43. Heinemann V, Moosmann N, Vehling-Kaiser U, et al (2007) XELIRI plus cetuximab versus XELOX plus cetuximab for firstline therapy of metastatic colorectal cancer (CRC): a randomized trial of the AIO CRC Study Group. In: Presented at the American Society of Clinical Oncology 2007 Gastrointestinal Cancers Symposium, January 19-21, 2007, Orlando, FL (abstract 278)

44. Heinemann V, Fischer Von Weikersthal L, Moosmann N et al (2006) Cetuximab + capecitabine + irinotecan (CCI) versus cetuximab + capecitabine + oxaliplatin $(\mathrm{CCO})$ as first line therapy for patients with metastatic colorectal cancer (CRC): preliminary results of a randomized phase II trial of the AIO CRC Study Group. J Clin Oncol 24(18s):158s (abstract 3550)

45. Cartwright T, Kuefler P, Cohn A et al (2008) Results of a phase II trial of cetuximab plus capecitabine/irinotecan as first-line therapy for patients with advanced and/or metastatic colorectal cancer. Clin Colorectal Cancer 7:390-397

46. Moertel CG, Fleming TR, Macdonald JS et al (1995) Fluorouracil plus levamisole as effective adjuvant therapy after resection of stage III colon carcinoma: a final report. Ann Intern Med 122:321-326

47. O’Connell MJ, Mailliard JA, Kahn MJ et al (1997) Controlled trial of fluorouracil and low-dose leucovorin given for 6 months as postoperative adjuvant therapy for colon cancer. J Clin Oncol $15: 246-250$

48. International Multicentre Pooled Analysis of Colon Cancer Trials (IMPACT) Investigators (1995) Efficacy of adjuvant fluorouracil and folinic acid in colon cancer. Lancet 345:939-944

49. Wolmark N, Rockette H, Mamounas E et al (1999) Clinical trial to assess the relative efficacy of fluorouracil and leucovorin, fluorouracil and levamisole in patients with Dukes' B and C carcinoma of the colon: results from National Surgical Adjuvant Breast and Bowel Project C-04. J Clin Oncol 17:3553-3559 
50. Haller DG, Catalano PJ, Macdonald JS et al (1998) Fluorouracil (FU), leucovorin (LV) and levamisole (LEV) adjuvant therapy for colon cancer: five-year final report of INT-0089. Proc Am Soc Clin Oncol 17:256a (abstract 982)

51. Arkenau HT, Bermann A, Rettig K et al (2003) 5-Fluorouracil plus leucovorin is an effective adjuvant chemotherapy in curatively resected stage III colon cancer: long-term follow-up results of the adjCCA-01 trial. Ann Oncol 14:395-399

52. Porschen R, Bermann A, Löffler T et al (2001) Fluorouracil plus leucovorin as effective adjuvant chemotherapy in curatively resected stage III colon cancer: results of the trial adjCCA-01. J Clin Oncol 19:1787-1794

53. Leichman CG (2006) Adjuvant therapy for colon cancer 2005: new options in the twenty-first century. Surg Oncol Clin N Am $15: 159-173$

54. Twelves C, Boyer M, Findlay $M$ et al (2001) Capecitabine (Xeloda) improves medical resource use compared with 5-fluorouracil plus leucovorin in a phase III trial conducted in patients with advanced colorectal cancer. Eur J Cancer 37:597-604

55. Twelves C, Wong A, Nowacki MP et al (2005) Capecitabine as adjuvant treatment for stage III colon cancer. N Engl J Med 352:2696-2704

56. André T, Boni C, Mounedji-Boudiaf L et al (2004) Oxaliplatin, fluorouracil, and leucovorin as adjuvant treatment for colon cancer. N Engl J Med 350:2343-2351

57. Kuebler JP, Wieand HS, O'Connell MJ et al (2007) Oxaliplatin combined with weekly bolus fluorouracil and leucovorin as surgical adjuvant chemotherapy for stage II and III colon cancer: results from NSABP C-07. J Clin Oncol 25:2198-2204

58. Schmoll H-J, Cartwright T, Tabernero J et al (2007) Phase III trial of capecitabine plus oxaliplatin as adjuvant therapy for stage III colon cancer: a planned safety analysis in 1, 864 patients. J Clin Oncol 25:102-109

59. Haller D, Tabernero J, Maroun J et al (2009) First efficacy findings from a randomized phase III trial of capecitabine + oxaliplatin vs. bolus 5-FU/LV for stage III colon cancer (NO16968/XELOXA study). Eur J Cancer Suppl 7:4 (abstract 5LBA)

60. Haller D, Cassidy J, Tabernero J et al (2010) Efficacy findings from a randomized phase III trial of capecitabine plus oxaliplatin versus bolus 5-FU/LV for stage III colon cancer (NO16968): no impact of age on disease-free survival (DFS). In: Presented at the American Society of Clinical Oncology Gastrointestinal Cancers Symposium, January 22-24, 2010, Orlando, FL (abstract 284)

61. Ward S, Kaltenthaler E, Cowan J et al (2003) Clinical and costeffectiveness of capecitabine and tegafur with uracil for the treatment of metastatic colorectal cancer: systematic review and economic evaluation. Health Technol Assess 7:1-93

62. Wiklund TA, Pekurinen M (2003) Pharmacoeconomic comparison of capecitabine vs. intravenous 5-FU/leucovorin (Mayo protocol) in colorectal cancer (CRC) in Finland T. Proc Am Soc Clin Oncol 22 (abstract 2134)

63. Cassidy J, Douillard JY, Twelves C et al (2006) Pharmacoeconomic analysis of adjuvant oral capecitabine vs. intravenous 5-FU/LV in Dukes' C colon cancer: the X-ACT trial. Br J Cancer 94:1122-1129

64. Virik K, Skedgel C, Younis T (2006) Economic evaluation of adjuvant chemotherapy in stage III (SIII) colon cancer: capecitabine versus 5FU/LV. J Clin Oncol 24(18S):312s (abstract 6046)

65. Di Costanzo F, Ravasio R, Sobrero A et al (2008) Capecitabine versus bolus fluorouracil plus leucovorin (folinic acid) as adjuvant chemotherapy for patients with Dukes' C colon cancer: economic evaluation in an Italian NHS setting. Clin Drug Investig 28:645-655
66. Chu E, Schulman KS, Zelt S et al (2009) Costs associated with complications are lower with capecitabine than with 5-fluorouracil in patients with colorectal cancer. Cancer 115:1412-1423

67. Garrison L, Cassidy J, Saleh M et al (2007) Cost comparison of XELOX compared to FOLFOX-4 with or without bevacizumab (bev) in metastatic colorectal cancer. J Clin Oncol 25(18S):182s (abstract 4074)

68. Scheithauer W, Cassidy J, Figer A et al (2007) A comparison of medical resource use for 4 chemotherapy regimens as first-line treatment for metastatic colorectal cancer (MCRC): XELOX vs. FOLFOX-4 bevacizumab (A). J Clin Oncol 25(18S):188s (abstract 4098)

69. Perrocheau G, Bennouna J, Ducreux M et al (2007) Cost-minimization analysis of a phase III study of capecitabine + oxaliplatin (XELOX) vs. infusional 5-FU/LV + oxaliplatin (FOLFOX-6) as first-line treatment for metastatic colorectal cancer (MCRC) in the French setting. J Clin Oncol 25(18S):184s (abstract 4083)

70. Shiroiwa T, Fukuda T, Tsutani K (2009) Cost-effectiveness analysis of XELOX for metastatic colorectal cancer based on the NO 16966 and NO 16967 trials. Br J Cancer 101:12-18

71. Hebbar M, Bennouna J, Boige V et al (2007) Safety and quality of life (QoL) findings from a randomized phase III study of capecitabine $(\mathrm{X})+$ oxaliplatin $(\mathrm{O})$ (XELOX) vs. infusional 5 -FU/LV + O (FOLFOX-6) in metastatic colorectal cancer (MCRC). J Clin Oncol 25(18S):188s (abstract 4099)

72. Comella P, Massidda B, Filippelli G et al (2009) Randomised trial comparing biweekly oxaliplatin plus oral capecitabine versus oxaliplatin plus i.v. bolus fluorouracil/leucovorin in metastatic colorectal cancer patients: results of the Southern Italy Cooperative Oncology study 0401. J Cancer Res Clin Oncol 135:217-226

73. Liu G, Franssen E, Fitch MI et al (1997) Patient preferences for oral versus intravenous palliative chemotherapy. J Clin Oncol 15:110-115

74. Twelves CJ (2006) Xeloda in Adjuvant Colon Cancer Therapy (X-ACT) trial: overview of efficacy, safety, and cost-effectiveness. Clin Colorectal Cancer 6:278-287

75. Pfeiffer P, Mortensen JP, Bjerregaard B et al (2006) Patient preference for oral or intravenous chemotherapy: a randomised cross-over trial comparing capecitabine and Nordic fluorouracil/ leucovorin in patients with colorectal cancer. Eur $\mathrm{J}$ Cancer 42:2738-2743

76. Ruddy K, Mayer E, Partridge A (2009) Patient adherence and persistence with oral anticancer treatment. CA Cancer J Clin 59:56-66

77. Kopec JA, Yothers G, Ganz PA et al (2007) Quality of life in operable colon cancer patients receiving oral compared with intravenous chemotherapy: results from National Surgical Adjuvant Breast and Bowel Project Trial C-06. J Clin Oncol 25:424-430 Erratum in: J Clin Oncol 2007;25:5540-5541

78. Kim JC, Kim TW, Kim JH et al (2005) Preoperative concurrent radiotherapy with capecitabine before total mesorectal excision in locally advanced rectal cancer. Int J Radiat Oncol Biol Phys 63:346-353

79. Craven I, Crellin A, Cooper R et al (2007) Preoperative radiotherapy combined with 5 days per week capecitabine chemotherapy in locally advanced rectal cancer. Br J Cancer 97:1333-1337

80. National Surgical Adjuvant Breast and Bowel Project (NSABP), National Cancer Institute (NCI), Cancer and Leukemia Group B. Radiation therapy and either capecitabine or fluorouracil with or without oxaliplatin before surgery in treating patients with resectable rectal cancer. ClinicalTrials.gov identifier NCT00058474. http://clinicaltrials.gov/ct2/show/NCT00058474. Accessed 16 July 2009 